\title{
Avrupalı Seyyahların Gözüyle Seydiköy ve Çevresi
}

\author{
Ali K. Öz $z^{\mathrm{a}, \mathrm{b}}$, Barış Gürc
}

\section{Özet}

Bu çalışmada Seydiköy'ü 17. yüzyıldan itibaren ziyaret etmeye başlayan Avrupalı seyyahların gezi anekdotlarında verdiği bilgiler ve 2018 yılında tarafımızdan gerçekleştirilen arkeolojik yüzey araştırması sırasında elde edilen bulgular üzerinden kentin arkeolojik ve kültürel mirasının mevcut durumu ile değişimi değerlendirilmiştir. Seydiköy'ü 17. yüzyıldan bu yana ziyaret eden Avrupalı seyyahlar yerleşim hakkında paylaştıkları genel bilgiler dışında bölgenin antik kalıntıları üzerine de gözlemlerini sunmuşlardır. Özellikle Seydiköy ve çevresinin Avrupa müzelerine eski eser sağlayabilecek bir arkeolojik zenginliğe sahip olduğu bu şekilde öğrenilmektedir. Sonrasında gerçekleştirilen araştırmalar da yörenin antik çağda Smyrna'ya uzanan güzergâh üzerinde stratejik bir noktada olduğunu göstermekle birlikte kentin büyüme ve gelişme sürecinde birçok antik kalıntının kaybolmuş olduğu görülmektedir. Örneğin birçok seyyahın gezi anekdotları içerisinde adı geçen tümülüslerden günümüzde yalnızca bir tanesinin muhafaza edilebilmiş olması bunun kanıtı niteliğindedir. Önceki araştırmalarda ve tarafımızdan gerçekleştirilen yüzey araştırması sırasında yörede arkeolojik bulgulara ulaşılması da erken dönem seyyahlarının Seydiköy'ün antik kalıntılarına ilişkin vurgularını desteklemektedir.
Anahtar Kelimeler

Seydiköy

Yüzey Araştırması

Arkeoloji

Seyyahlar

Makale Hakkında

Geliş Tarihi: 12.12.2018

Kabul Tarihi: 19.12.2019

Doi: 10.18026/cbayarsos.496319

\section{Seydiköy and Its Surroundings From the Eyes of European Travelers}

\begin{abstract}
In this study, the information given in the anecdotes of European travelers, who started to visit Seydiköy from the 17th century, and the findings obtained during the archaeological survey conducted by us in 2018 were evaluated with the current state of the archaeological and cultural heritage of the city. Besides the general information they shared about the settlement, the European travelers who visited Seydiköy since the 17th century also presented their observations on the ancient ruins of the region. Especially, it is learned that Seydiköy and its surroundings have an archaeological prosperities that can provide ancient works to European museums. Afterwards, the researches show that the region is at a strategic point on the route extending to Smyrna in ancient times but many ancient ruins have been lost in the city's growth and development process. In previous researches and during the survey conducted by us, reaching the archaeological findings in the region also supported the early travelers of ancient ruins of Seydiköy.
\end{abstract}

Keywords

Seydiköy

Survey

Archaeology

Travelers

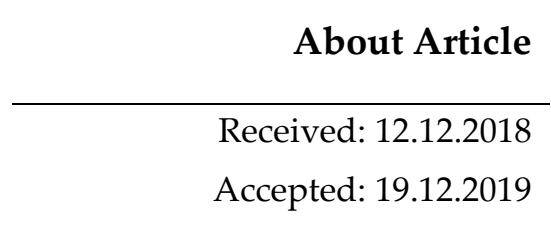

Doi: 10.18026/cbayarsos.496319

a İletişim Yazarı: ali.oz@deu.edu.tr

b Doç. Dr., Dokuz Eylül Üniversitesi, Edebiyat Fakültesi, Arkeoloji Bölümü. ORCID: 0000-0002-3005-3236

c Dr. Öğr. Üyesi, Dokuz Eylül Üniversitesi, Edebiyat Fakültesi, Müzecilik Bölümü. ORCID: 0000-0002-9031-9159 


\section{Giriş}

Bu çalışmada Seydiköy'ü 17. yüzyıldan itibaren ziyaret etmeye başlayan Avrupalı seyyahların gezi anekdotlarında verdiği bilgiler ve 2018 yılında tarafımızdan gerçekleştirilen arkeolojik yüzey araştırması sırasında (1) elde edilen bulgular üzerinden kentin arkeolojik ve kültürel mirasının mevcut durumu ile değişimi değerlendirilecektir. Seyyahların gezi anekdotlarında belirtmiş olduğu bilgiler üzerinden konuya yaklaşılarak Seydiköy ve çevresindeki mevcut arkeolojik ve kültürel mirasın günümüzdeki koruma durumunun ve değişiminin belgelenmesi ve irdelenmesi çalışmanın ana konusunu oluştururken, kentin arkeolojik mirasına ilişkin yüzey araştırması yoluyla elde edilen bulgular da ana hatlarıyla aktarılacaktır.

\section{Avrupalı Seyyahlar ve Seydiköy}

Avrupalı Seyyahlar 17. yüzyıldan itibaren İzmir'e gerçekleştirmiş oldukları yolculuklarında Seydiköy ve çevresini de ziyaret etmişlerdir. Bu ziyaretlerinde Seydiköy'ü Bornova, Narlıköy (Narlıdere), Boudja (Buca) gibi kent merkezinin dışında ancak merkeze uzak olmayan, bu nedenle de kısa sürede ulaşılabilen bir banliyö olarak gördükleri anlaşılmaktadır. Yerleşimi ve çevresini ziyaret eden seyyahlar günlüklerinde burayı Sedicui, Sedikeui, Sedikeuy, Sedekio, Sedjagui gibi farklı telaffuzlar ile tanımlamışlardır.

Avrupalı seyyahların gezi anekdotlarında Seydiköy, İzmir'den uzak olması ile Avrupalı konsolos ve tüccarların yaz aylarında dinlenebildikleri bir sayfiye yeridir. Richard Chandler, İzmir'e geldiğinde Seydiköy'e gerçekleştirmiş olduğu ziyaretinde yerleşimden küçük bir köy olarak tanımlamaktadır. Seydiköy'e geldiğinde Bay Lee'nin evinde kalmış, geliş nedeni olarak ise İzmir'deki büyük bir salgından sığınmak için burada bulunmaktadırlar (Chandler, 1817: 124). Seydiköy'ün İzmir'den uzakta olması ve nüfusunun az olması nedeniyle salgın hastalıkların fazlaca uğramadığı bir yer olduğu görülmektedir (2). Bu yönüyle İzmir'de yaşayan konsolosların, tüccarların hem yazlarını geçirdikleri hem de salgın hastalık durumlarında evlerine kapandıkları bir dinlenme yeridir.

Avrupalı konsoloslar ve tüccarlar için İzmir'in dışında kalan ancak kısa mesafede kolayca ulaşabilecekleri doğal güzelliklere sahip yerleşimler yazları ikamet edilmek üzere tercih edilmekteydi. Konsolos ve tüccarlar için büyük bahçelere sahip kır evleri büyük bir konfora sahipti. Bu tercihler içerisinde Seydiköy'ün de önemli bir yeri vardı. John Fuller'ın 1818'daki gözlemlerine göre farklı ulusların İzmir'in dışındaki farklı yerleşimleri bir bakıma seçmiş, adeta dinlenme amacıyla aralarında paylaşmış oldukları görülmektedir.

Francis Arundell Seydiköy'deki konsolos evlerini sayarken, önceki Hollanda konsolosu Hochepied'in dul eşinin, görevdeki Hollanda konsolosu Van Lennep'in, kardeşi İsveç Konsolosu'nun, İngiliz konsolosu Werry'nin güzel evlerini görmüştür. Arundell 300 Yunan evi, 40 Türk evi ile köyün bir kilisesi ve camisinin bulunduğu bilgisini vermektedir (Arundell, 1828: 12).

Fredrik Hasselquist için Seydiköy'ün anlamı ise biraz daha farklıdır. Seydiköy'ü olağanüstü bir yer olarak tanımlamasının ardında yatan, burada kendisinin tabiriyle botanik dünyasının kralı Sherard'ın gerçekleştirmiş olduğu çalışmalardır. Hasselquist,Sherard'ın bir botanik koleksiyonu meydana getirmiş olduğu bahçesini ve evini görmüş olduğunu belirtmektedir (Hasselquist, 1766: 51). 
Henry Alexander S. Dearborn, Seydiköy için Smyrna'nın güneyinde kente bir buçuk saat uzaklıkta büyüleyici bir köy tanımını yaparken Türkçe isminin "Aşk köyü" anlamına geldiğini belirtmektedir (Dearborn, 1819: 64). Jean Joseph François Poujoulat'nın Michaud'a yazmış olduğu 1830 yılındaki mektupta ise Pagos Dağı'nı aşıp iki saatlik bir yürüyüş sonrasında Seydiköy'e sevgi ve aşk köyüne gelmiş olduklarını belirtirken, çevresinde epey küçük köycükler olan bu yerleşimi büyük bir afet nedeniyle İzmir tabutlar şehri haline gelince Chandler'in çekildiği köy olarak tanıtmaktadır (Michoud \& Poujoulat, 2007: 81). Seydiköy Thomas MacGill için ise İzmir ziyareti sırasında, körfezin doğusundaki çekilip uyuyup dinlendikleri hoş bir köydü (MacGill, 1839: 140). Charles Fellows ise Seydiköy'ü seyahatnamesinde "Sideecooe" olarak yazarken, güzel bir köy olarak tanımlamaktadır (Fellows, 1839: 7).

Farklı bir anekdotu ise John Fuller'ın seyahatnamesinden gözlemlemek mümkündür. Atla yolculuğu sırasında düşerek yaralanan İngiliz, Seydiköy'e götürülmüş ve burada yine bir İngiliz cerrah tarafından tedavi edildikten üç gün sonra iyileşerek İzmir'e geri dönmüştür (Fuller, 1830: 40).

Francis Arundell de Seydiköy'ün bozulmamış doğal güzelliğini ve vahşi doğasını aktaran seyyahlardan biridir. Seydiköy'ün vahşi hayvan türleri bakımından çeşitliliğine vurgu yapan Arundell, Seydiköy'ün çevresinin çakal sürüleri ve yaban domuzları bakımından bol olduğunu, iki yıl önce ise bir Hyaena'nın (sırtlan) Seydiköy ile Buca arasında öldürülmüş olduğu bilgisini vermektedir. Bununla birlikte kendisinin Seydiköy ile Ephesos (Selçuk) arasında kurtlarla sıklıkla karşılaşılmış olduğunu ancak Nymphaeum'a (Kemalpaşa) giden yol üzerinde birkaç yıl önce aslan, dağlarında ise vaşak görüldüğünü belirtmektedir (Arundell, 1828: 302).

Edwin John Davis, 1872 yılında İzmir'i ziyaretinde kentin çevresine ilişkin gözlemlerinde Buca'nın ötesinde büyük bir köy olarak nitelendirdiği Seydiköy'ün yakınında görkemli selvi koruluğu bulunduğunu belirtir. Seydiköy ovasının ise; kısmen tarıma alınmış olup üzüm bağları, buğday tarlaları ve tepelerin yamaçlarındaki zeytin bahçeleri ile verimli topraklara sahip olduğunu aktarır (Davis, 1874: 25). Hugh Edwin Strickland'ın Seydiköy üzerine vermiş olduğu bilgiler ise yerleşimin daha çok jeolojik yapısı üzerinedir (Jardine, 1858: 11-12). Özellikle incelemelerinde Seydiköy ve Buca arasındaki ana bölgenin beyaz ve yeşilimsi marl ile kireçtaşı tabakalaşması bakımından yoğun olduğunu saptamıştır (Jardine, 1858: 11).

\section{Geçmişten Günümüze Seydiköy'ün Arkeolojik Mirası}

Bu bölümde 17. yüzyıldan itibaren Seydiköy ve çevresini ziyaret ederek arkeolojik kalıntılara ilişkin gözlemlerde bulunan Avrupalı seyyahların doğrudan deneyimlemiş olduğu bulguların 2018 yılında gerçekleştirmiş olduğumuz Gaziemir ve çevresindeki yüzey araştırması ile irdelenerek, değerlendirilmesi amaçlanmıştır. Bu yönüyle çalışmada 200 yıldan fazla bir süre içerisinde kent ölçekli değişim ve gelişimin etkileri, arkeolojik mirasın korunan, tahribata uğrayan, yok edilmiş unsurları ortaya koyulabilecektir (Şekil 1). 


\section{Akçakaya}

İzmir kent merkezine en yakın savunma sistemi olarak görülen Akçakaya, GaziemirKarabağlar sınırında Kızıldağ'ın (Mastousia) eteklerinde yer almaktadır. Akçakaya üzerine ilk kez incelemeler yaparak yayınlayan kişi Georg Weber'dir. 1882 yılında Weber kireçtaşından bir tepe üzerine kurulan yer yer savunma duvarları ile çevrelenmiş olan bir kaleyi belgelemiştir. Weber, Akçakaya üzerine gözlemlerinde yamaçtaki ilk terasta 40x35 m ölçülerinde antik bir yapının varlığından söz etmektedir (Weber, 1885: 213-214). Bununla birlikte yapının içinde duvar kalıntılarının korunduğu bilgisini vermiştir. Akropole çıktığında Weber için en dikkat çekici olan ise iyi korunmuş olan sarnıçtır. Taş bloklardan inşa edildiğini belirttiği sarnıcın $4.70 \mathrm{~m}$ uzunluğunda genişliğinin $3.10 \mathrm{~m}$ derinliğinin ise $3 \mathrm{~m}$ olduğu bilgisini vermektedir (Weber, 1885: 215), (Şekil 2-4). Cecil John Cadoux'un gözlemleri de eski bir akropolisten kalma yıkıntılar ile surlarla çevrelenen bir alanın içindeki yapılar ve büyük bir sarnıcı içermektedir (Cadoux, 2003: 76).

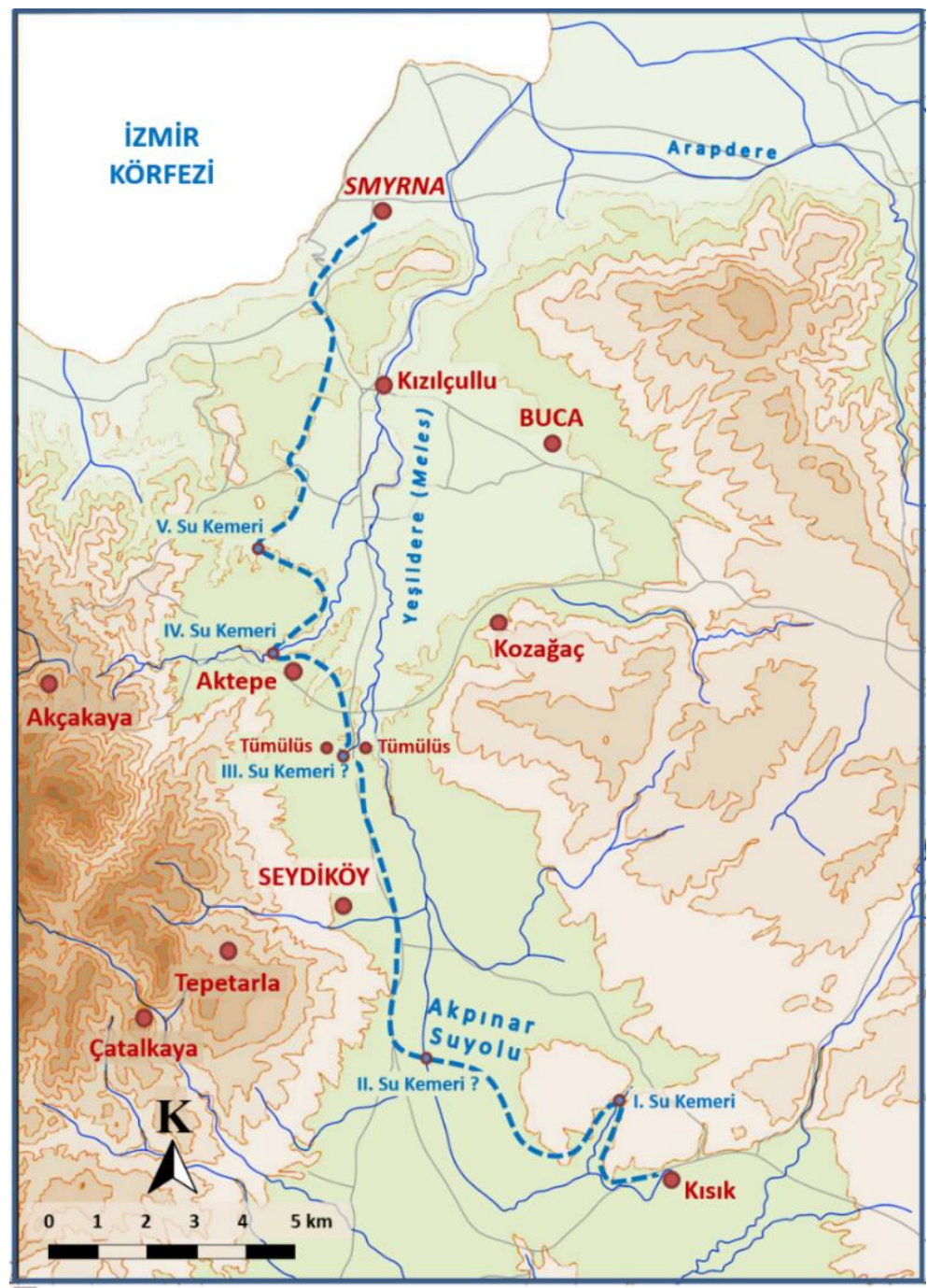

Şekil 1. Seydiköy ve çevresini içeren harita

Akçakaya konum itibariyle hem Gaziemir ovasına hem de İzmir kıyılarına hâkimdir (Resim 3-4). Yaklaşık $65 \times 40 \mathrm{~m}$ boyutlarındaki kalenin surları, Geç Klasik döneme uygun isodomos düzeninde ve yerel pembe kireçtaşından yapılmıştır. Surların güneybatısındaki doğal bir geçit vasıtasıyla kaleye ulaşılabildiği varsayılmaktadır. 
Kalenin içinde zirveye yakın bir noktada kutsal alan izlenimi veren basamaklı bir oluşum görülmektedir (Şekil 5-6). Yaklaşık 2,80x2,10 m boyutlarındaki basamaklar ve platform anakaya oyularak uygulanmıştır. Doğuya bakan yapıya iki basamak ile çıkıldıktan sonra yanlarında yükseltiler olan taht formunda, 1,39x0,94 m ölçülerinde bir platformla karşılaşılmaktadır. Platformun arkasında bir niş ve nişten sarnıca doğru giden, anakayaya oyulmuş bir kanal bulunmaktadır. Kutsal alan izlenimi veren oluşumun etrafında boyutları $48 \times 24 \times 12 \mathrm{~cm}$ ve 46×26×18 cm olan fakat bilinçli olarak parçalara ayrılmış iki adet granit ögütme taşı ele geçmiştir. Benzer ögütme taşları, Olynthos Değirmeni veya Roma'da mola trusatalis (baskı değirmeni) olarak adlandırılan değirmenlerde besleme hunisi olarak kullanılmaktaydı (Frankel, 2003: 1-21). Ayrıca aynı yerde kırılmış halde 39x23x12 cm ölçülerinde tüf taşından buğday teknesine de rastlanmıştır.

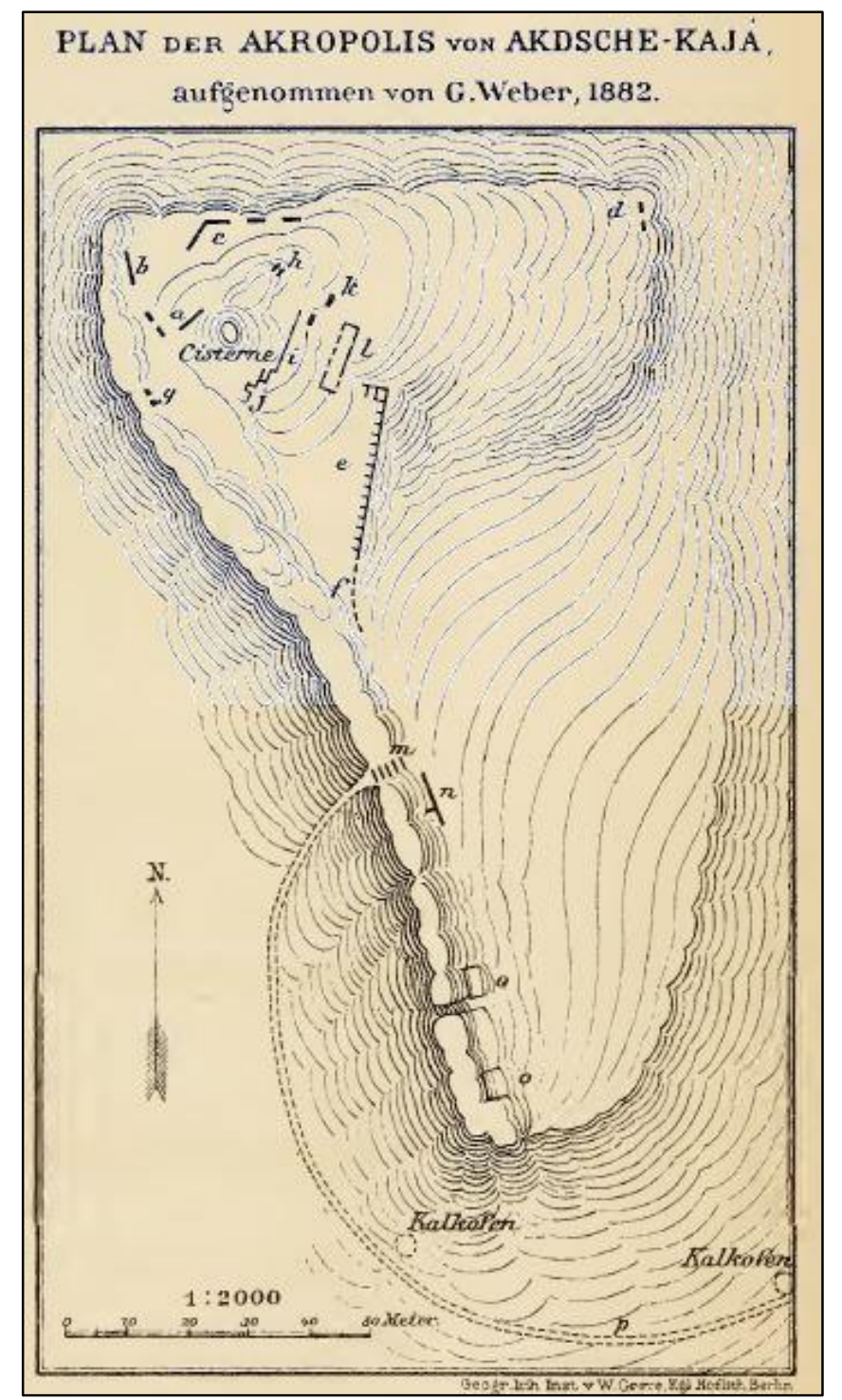

Şekil 2. Akçakaya'nın Planı (Weber 1885, 21) 


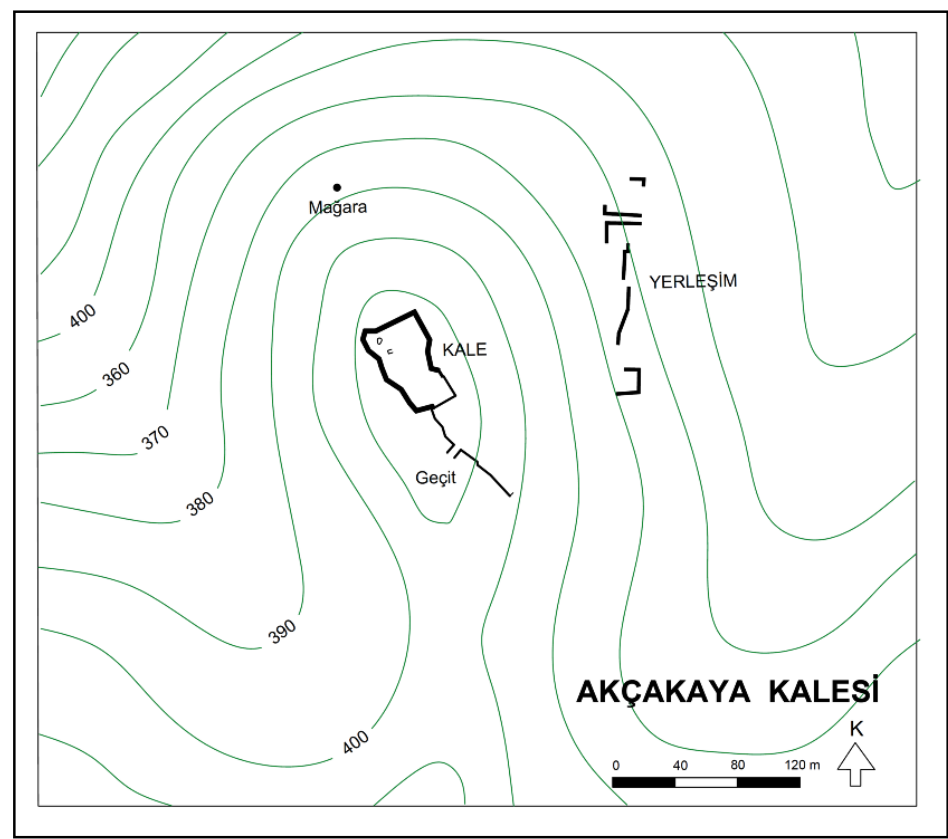

Şekil 3. Akçakaya'nın Planı (Çizim: A. K. Öz)

Akçakaya Akropolü'nde ana kayaya oyulmuş basamak sırası ve gerisinde yer alan kesme taşlardan düzenli bir şekilde oluşturulmuş olan sarnıç hala kısmen korunur durumdadır. 386x282 boyutlarında oval biçimli sarnıcın ölçülebilen derinliği 4,70 metredir. $+417 \mathrm{~m}$ yükseklikte zirvede yer alan Roma dönemi özellikleri gösteren sarnıcın harçlı duvarları, yaklaşık $30 \mathrm{~cm}$ yüksekliğinde kesme taş bloklarla örülmüştür.

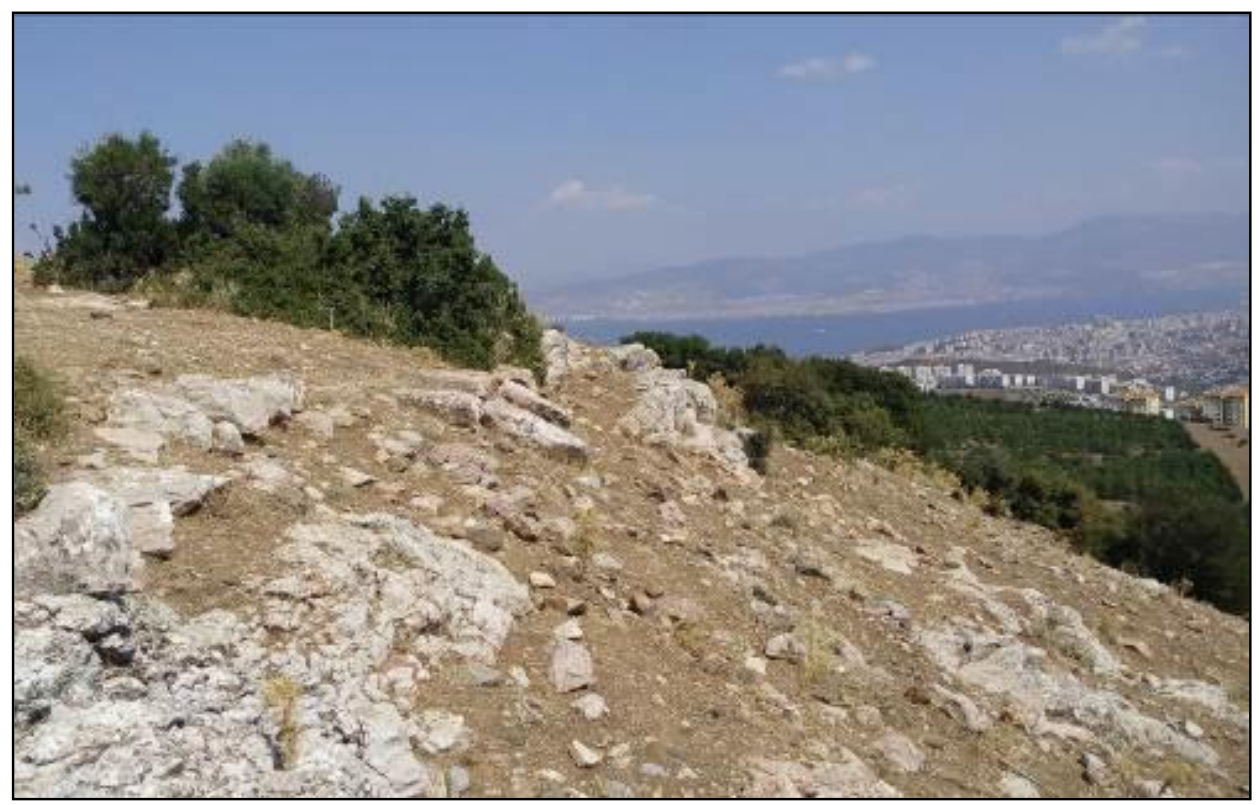

Şekil 4. Akçakaya Akropolü 


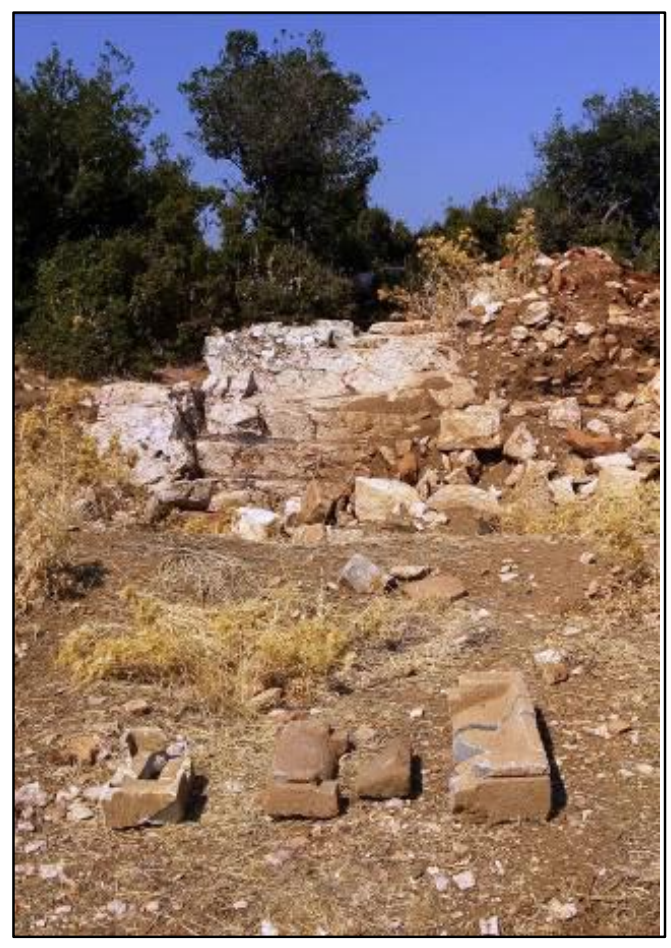

Şekil 5. Akçakaya Akropolü basamaklı platform ve çevresi

Akropol'de kesme taş blok parçalarını, bazı mimari yapılara ilişkin üst yapı parçaları ile Akçakaya'nın savunma duvarına ilişkin kalıntıları yer yer gözlemlemek mümkündür. Buna karşın Weber'in haritasında e ve f harfleriyle belirtmiş olduğu kuzey-güney doğrultusunda 25 metreye ulaşan sur duvarının kalıntıları ise büyük ölçüde kaybolmuştur.

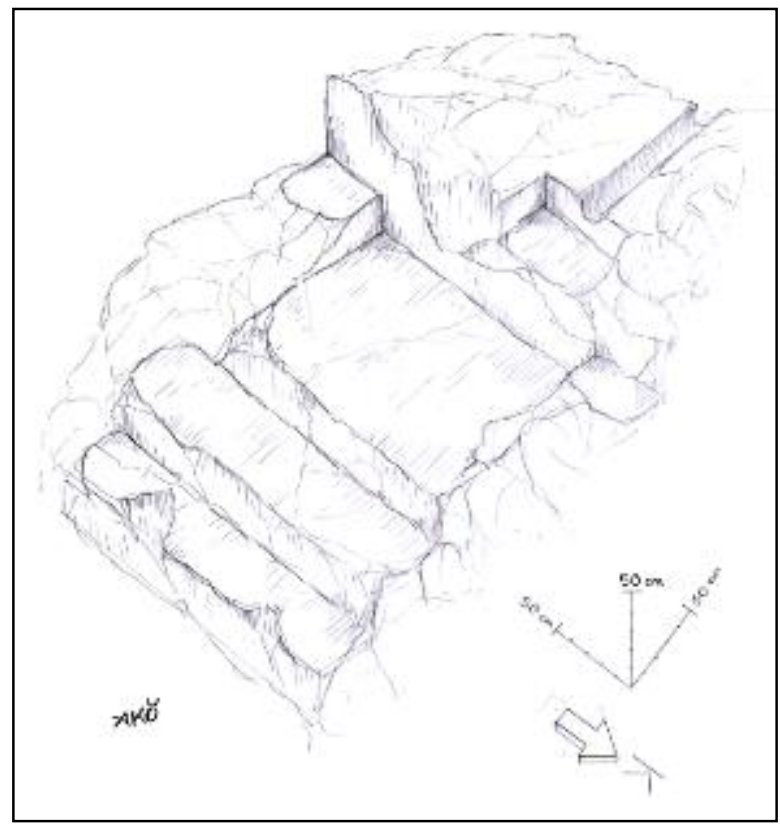

Şekil 6. Akçakaya Akropolü basamaklı platform çizimi (Çizim: A. K. Öz) 


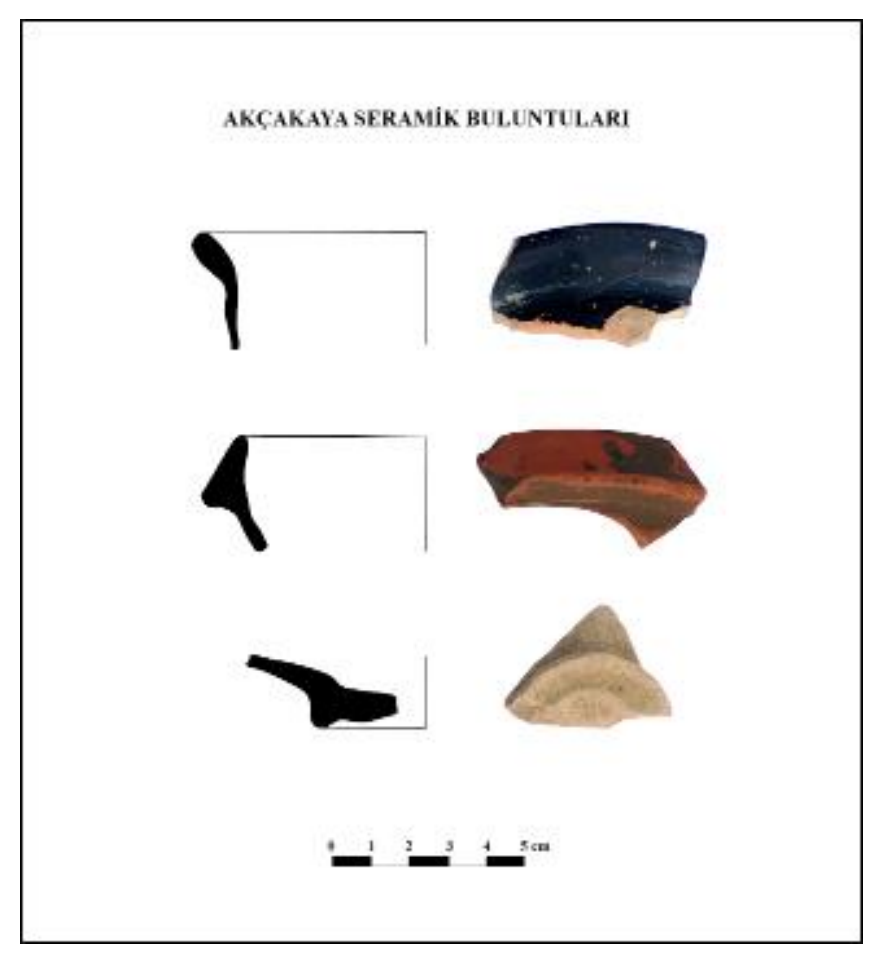

Şekil 7. Akçakaya Akropolü seramik buluntuları

Akçakaya kalesinin doğu eteklerinde yaklaşık +369 m seviyelerinde bir yerleşime ait duvar kalıntıları görülmektedir. Kuzey-Güney yönünde teraslar halinde görülen duvarlar, birbirine paralel tasarlanmış çeşitli boyutlarda mekânlara aittir. Güneye doğru yaklaşık $146 \mathrm{~m}$ takip edilebilen duvarların en fazla $25 \mathrm{~m}$ kadar uzunluğa sahip olduğu tespit edilmiştir. Yerleşim yerindeki seramikler kale ile aynı döneme (Geç Klasik-Bizans arası) ve özelliklere sahip parçalardan oluşmaktadır (Şekil 7). Ayrıca yüzeyde bulunan yerel kireçtaşından bir sütun, bir mortarium (buğday öğütme çanağı), cam ve seramik cürufları bu bölgede endüstriyel üretime yönelik bir yerleşme olduğunu kanıtlamaktadır. Tüm korunagelen arkeolojik kalıntılara karşın Akçakaya Akropolü'ndeki ve yamaçlar boyunca açılmış olan günümüzdeki çukurlar tepenin kaçak kazılar yoluyla zarar gördüğünü açı biçimde göstermektedir.

Akçakaya'nın stratejik konumu Geç Klasik dönemden Bizans dönemine kadar kalenin önemini koruduğunu göstermektedir. Doğer'in vurguladığı üzere Akçakaya'nın güney istikameti üzerinde stratejik bir görevi bulunmaktaydı. Yeşildere vadisi üzerinden Kolophon, Metropolis ve Ephesos'a giden güney-güneybatı yolu Kızıldağ ve Kolophon üzerinden gelebilecek saldırılara karşı Çatalkaya'nın yanı sıra Akçakaya kalesi de önemli bir savunma merkezi konumundaydı (Doğer, 2006: 87).

\section{Tümüliüsler}

Gaziemir'deki yüzey araştırmaları sırasında birçok Avrupalı seyyahın gezi anekdotlarında altını çizmiş oldukları, gözlemlerini aktarmış oldukları tümülüslerin bulunup mevcut durumlarının tespit edilmesi üzerine de çalışmalar gerçekleştirilmiştir.

Öncelikle Avrupalı seyyahların bu konudaki verdiği bilgileri incelediğimizde bir misyoner olan Pliny Fisk 1821 yılında Seydiköy'den dönüşünde, yollarının batısında bir tümülüs görmüş ve aktardığ1 ölçülerde çevresinin yaklaşık 150 metre (30 rods) olduğu bilgisini vermiştir (Bond, 1828: 138). Smyrna ve Seydiköy arasında çeşitli tümülüslerin görülebildiğini 
söyleyen Dearborn ise bunlardan birinin Hektor'ın eşi Andromakhe'nin mezarı olduğunu vurgulamaktadır (Dearborn, 1819: 64). Tümülüsleri gören birçok seyyah bulunmaktadır; zira James Emerson da Seydiköy'ün iki mil uzağında yol kenarında bir tümülüsün varlığından söz etmektedir (Emerson, 1829: 71). Oldukça büyük boyutlardaki bu tümülüsün Ion Kolonizasyonu sırasında görev alan liderlerden Andremon'un mezarı olarak nitelendirmektedir. Köyün yakınlarında bir çeşme yer alırken söz konusu çeşmenin Aziz John'a adanmış olduğu bilgisini vermektedir.

Arundell de tümülüslere ilişkin saptamalarda bulunmuştur. Belirttiği üzere Seydiköy'den yarım saat uzaklıkta yolun sağındaki derenin yakınlarında biri küçük, diğeri ise yolun soluna yakın bir noktada iki tümülüs yer almaktaydı. İlk sözünü ettiği tümülüsün Kolophon'un kurucusu Andremon'un mezarı olduğunu Arundell de tekrar etmektedir (Arundell, 1828: 11). MacGill İzmir' den söz ederken lafı kaleye ve dağın solundaki su kemerine getirmekle birlikte, Seydiköy yolu üzerinde iki büyük tümülüsün görüldüğünü ve benzer biçimde diğger seyyahlar gibi bunlardan birinin Andromakhe'ye ait olduğu bilgisini verirken, gördüğü haliyle tümülüslerin tamamen çalılarla kaplanmış olduğunu belirtmektedir (MacGill, 1839: 142).

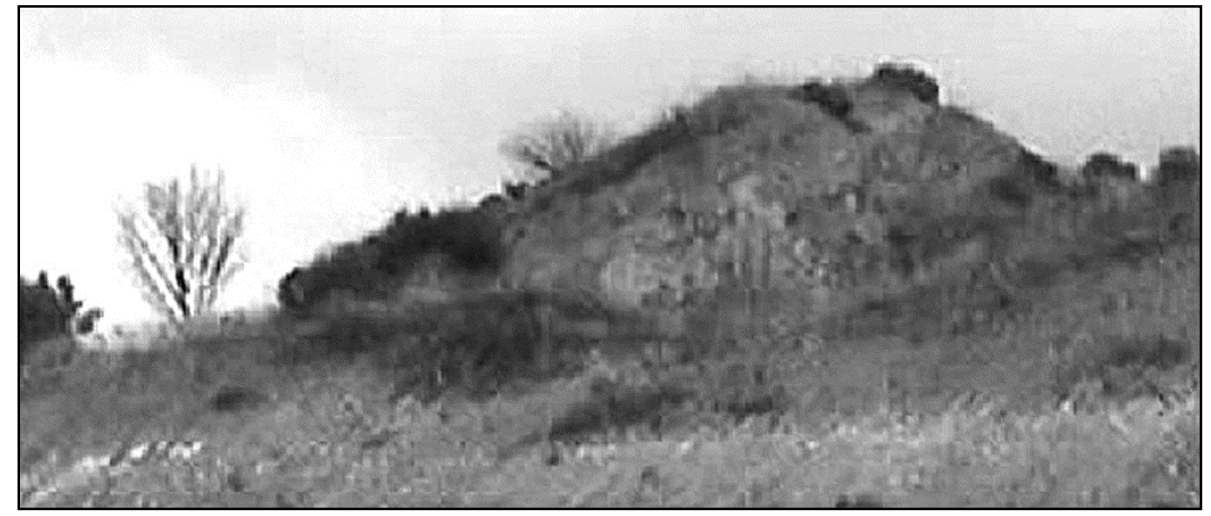

Şekil 8. Bulunduğu alana Avm yapılan tümülüs (E. Çokbankir Arşivi)

Seyyahların sözünü etmiş oldukları tümülüsler hakkında 2018 yılı Gaziemir yüzey araştırması sırasında incelemelerde bulunulmuştur. Sözü edilen tümülüsler içerisinde günümüzde yalnızca ikisinin yeri bellidir. İlki günümüzde Optimum Alışveriş Merkezinin bulunduğu alanda, 1482 ada, 47 parselde yer almaktadır. İzmir 1 Nolu Kültür ve Tabiat Varlıklarını Koruma Kurulu tarafından 24.10.2008 tarih ve 3577 sayılı kararı ile tümülüs için koruma kararı alınmasına karşın daha sonra imar izni verilerek tümülüs 50 m öteye taşınmış ve yerine AVM yapılmıştır. Bu nedenle söz konusu tümülüse ilişkin bulgulara ulaşılamamıştır (Şekil 8). 


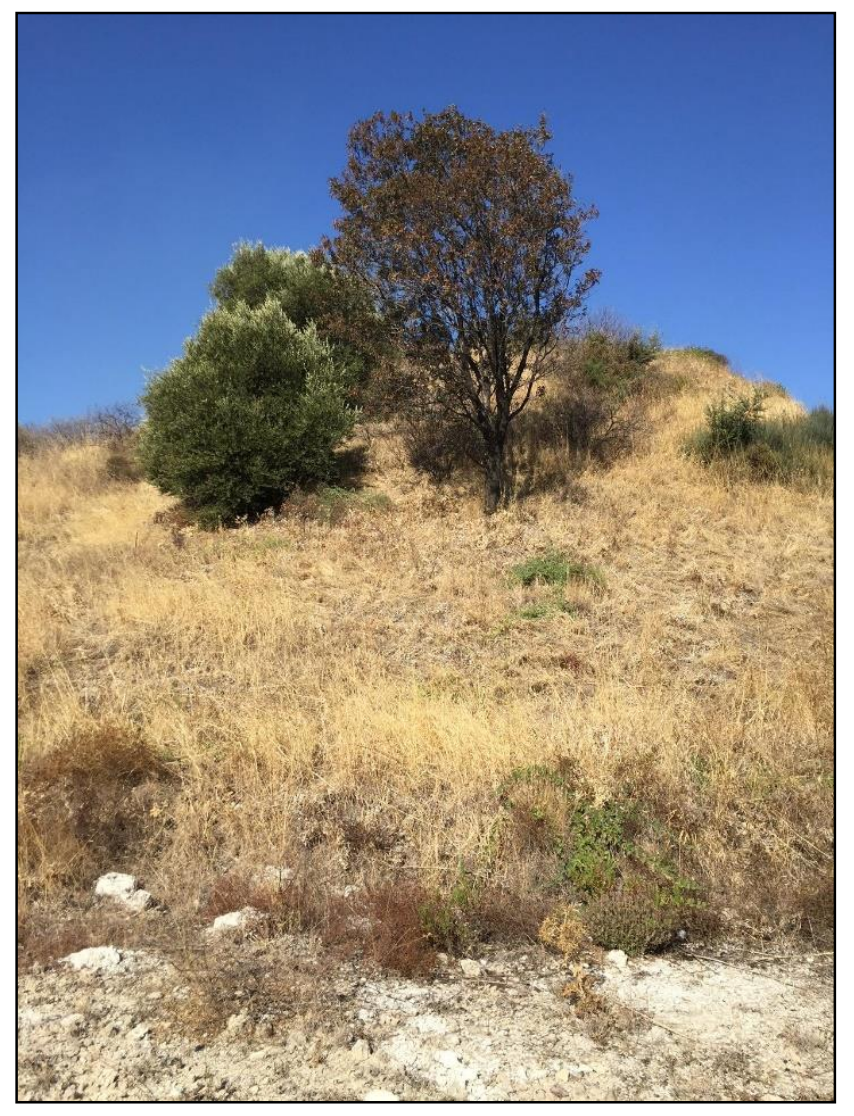

Şekil 9. Ege Serbest Bölgesi'ndeki tümülüs

İkincisi ise Ege Serbest Bölgesi sınırları içerisinde yer alan tümülüstür (Şekil 9-10). ESB'nin kurulduğu 1990 yılından beri çitlerle çevrili bir biçimde koruma altında tutulan tümülüs günümüzde Roy Robson Fabrikasının karşısında, Anes Tekstilin yanındaki alanda yer almaktadır. Tümülüs yaklaşık $60 \mathrm{~m}$ çapında ve $15 \mathrm{~m}$ yüksekliğindedir. İlk sekiz metresinin kumtaşı anakaya olduğu ve bunun krepis (çevre duvarı) olarak kullanıldığı, geri kalan yedi metrede ise sıkıştırılmış yığma topraktan bir tepecik yaratıldığı görülmektedir. Tepe üzerinde derin kaçak kazı çukurları olmasına rağmen henüz mezar odasına ulaşıldığına dair bir belirti veya buluntu yoktur. Ağaçlarla çevrelenen ve üzerini otların bürüdüğü tümülüs üzerindeki incelemelerde az sayıda kaba seramik parçaları bulunmuştur. Seyyahlar tarafından sözü edilen diğer tümülüslerin kentin gelişimi sırasında tamamıla yok edilmiş olduğu anlaşılmaktadır. 


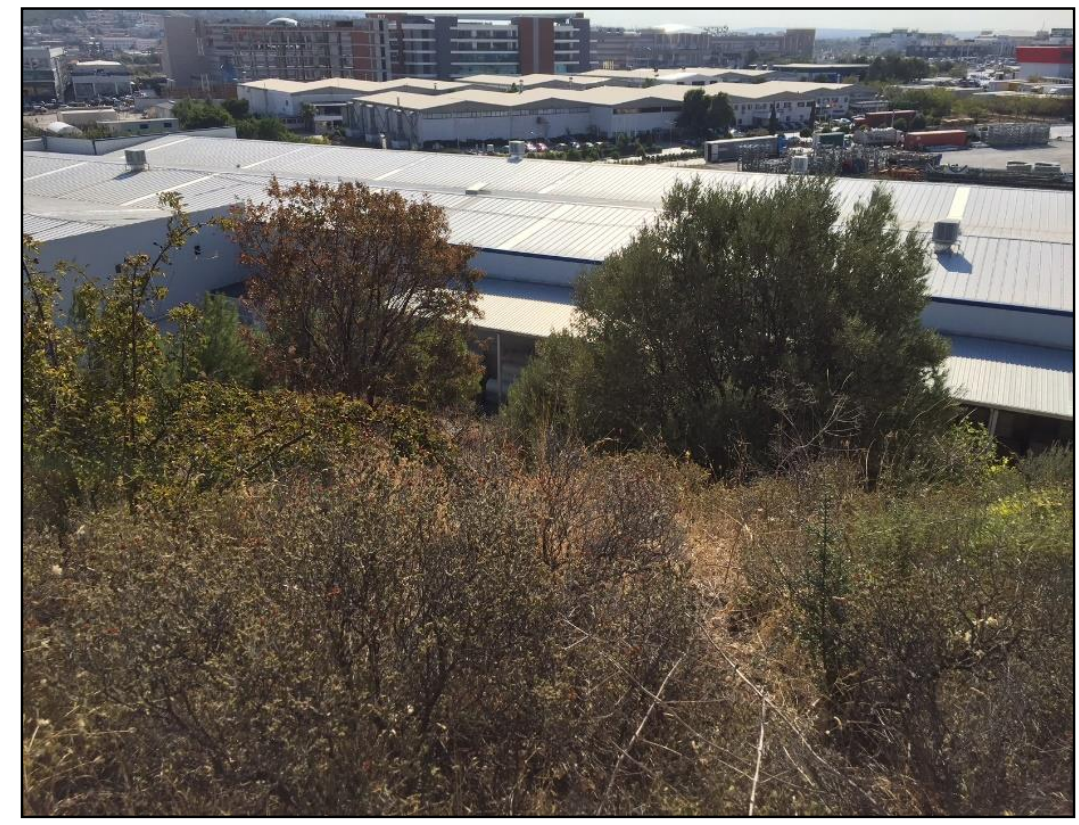

Şekil 10. Ege Serbest Bölgesi'ndeki tümülüsten bakış

Seydiköy'de bulunan fakat tahrip edilerek yok edildiği için günümüze ulaşamayan üçüncü bir tümülüs daha vardır. Söz konusu tümülüsün merkez pazaryeri ile mezarlık arasında kalan tarlada yer aldığı ve bir zamanlar tümülüsün bulunduğu bu alanın halk arasında "tümbe" olarak adlandırıldığı bilinmektedir (Şekil 11). Bununla birlikte yüzey araştırmaları sırasında söz konusu tümülüse ilişkin hiçbir bulguyla karşılaşılamamıştır.

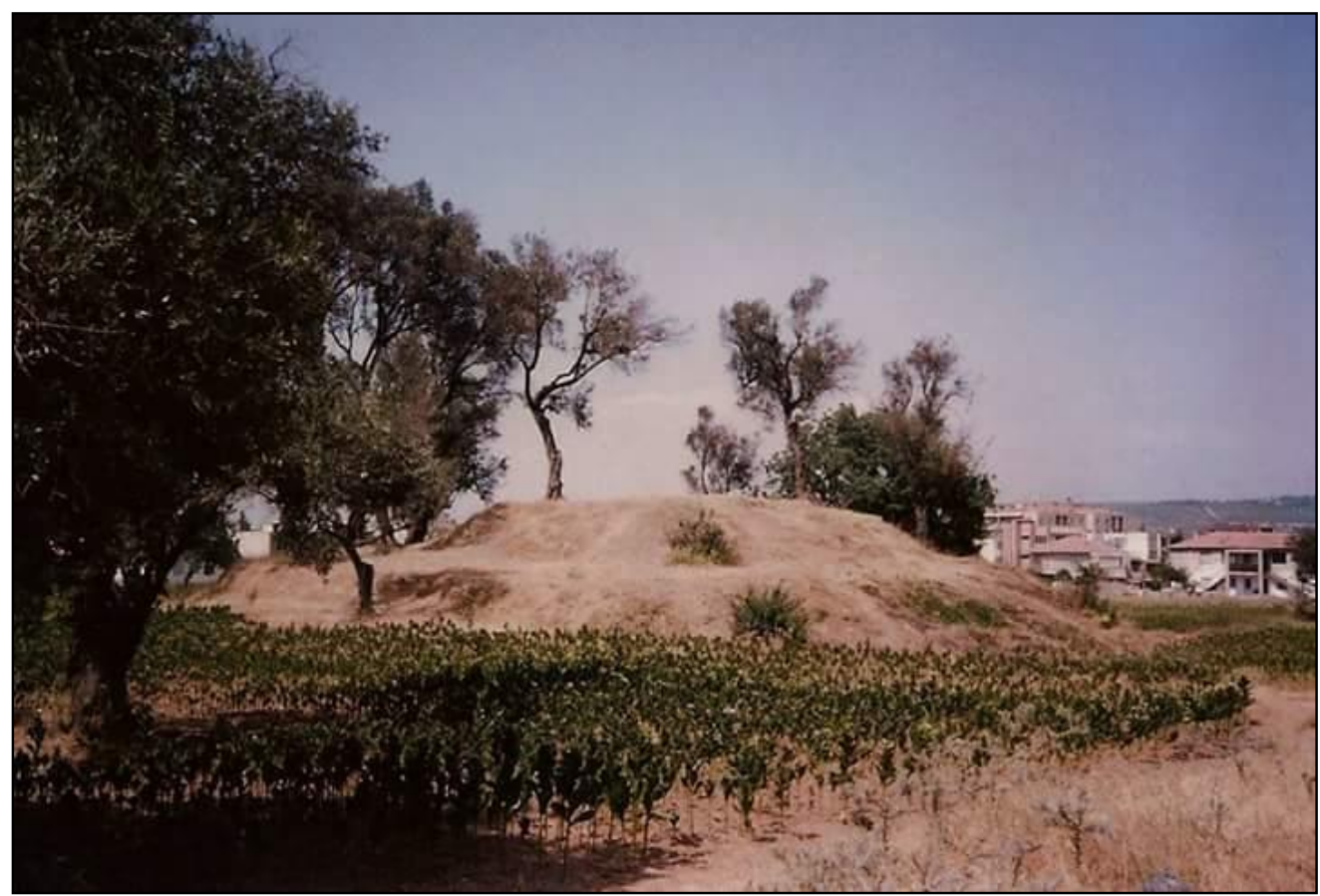

Şekil 11. Seydiköy'deki “tümbe” olarak adlandırılan alanda yer alan tümülüs (E. Çokbankir Arşivi) 
Weber 1899 haritasında verilen III. Su Kemeri'nin de ESBAŞ içindeki dere üzerinde yer aldı̆̆ı, dere ıslahı ve fabrika inşaatları sırasında yıkıldığı düşünülmektedir. 2018 yılı çalışmalarında Gaziemir, Sakarya Mahallesi sınırları içinde, yerel halk tarafından tümülüs olabileceği ileri sürülen iki alanda daha inceleme yapılmış fakat kesin bir sonuç elde edilememiştir.

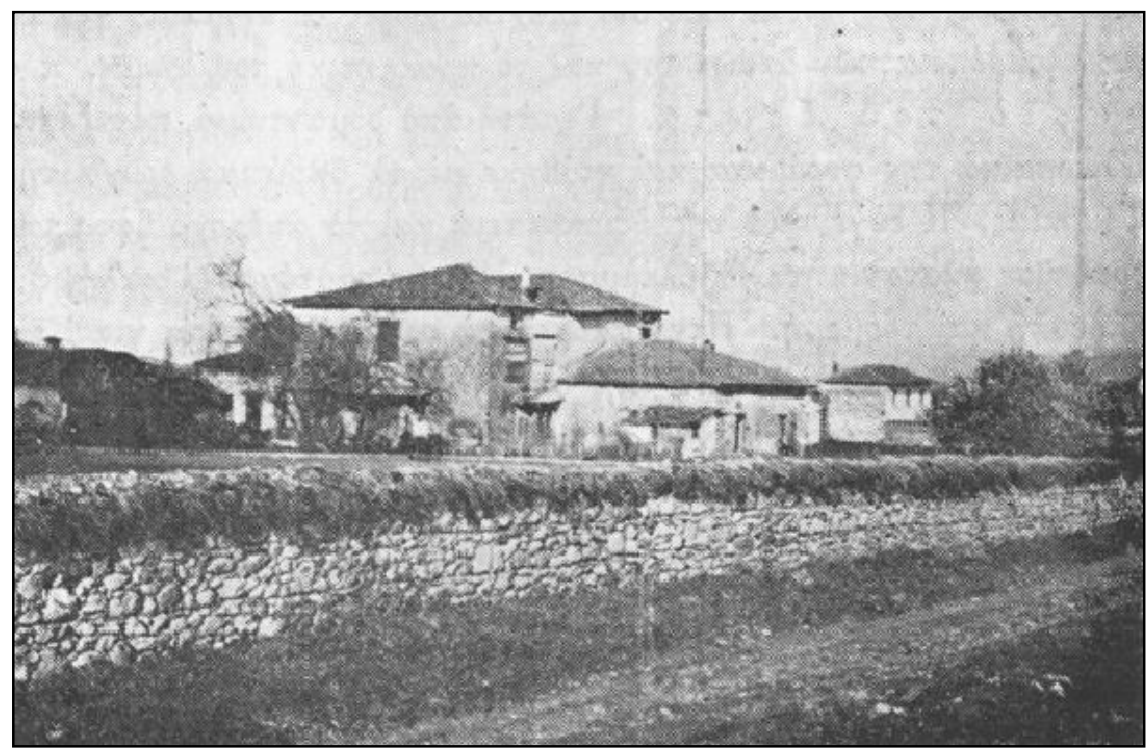

Şekil 12. Hochpied'in Evi, Seydiköy

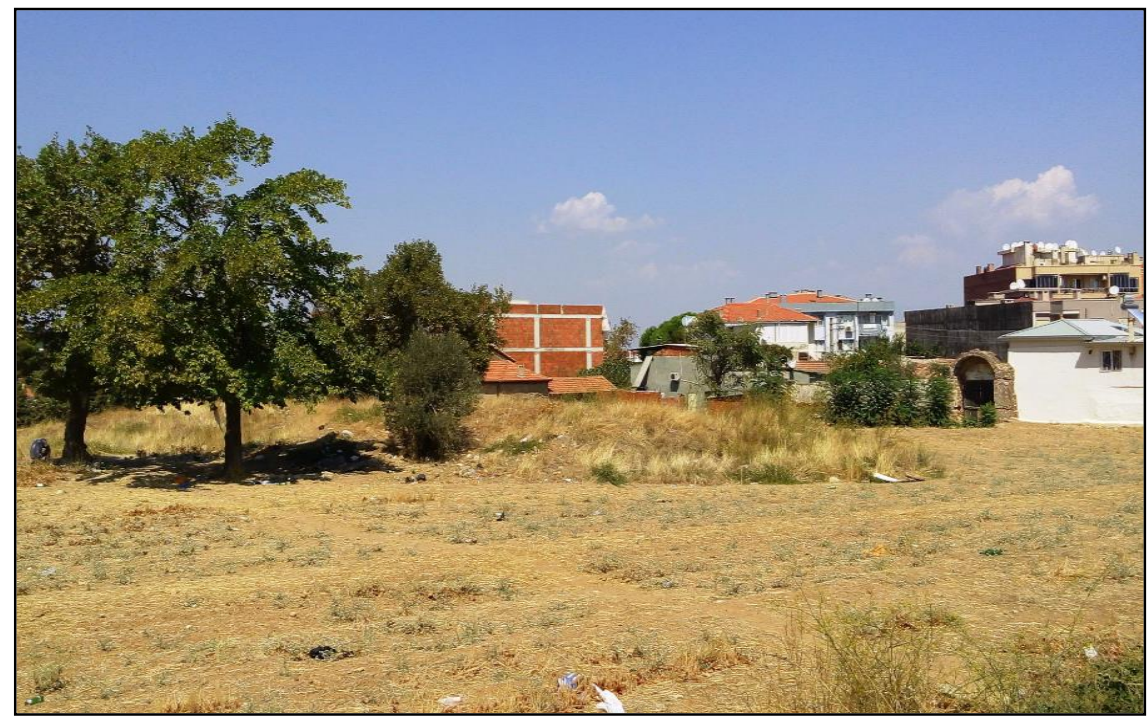

Şekil 13. Günümüzde Hochpied'in Evi'nin olduğu alan

\section{Hochepied'in Evi ve Eski Eserler}

Seydiköy'de en çok iz bırakmış Avrupalılar arasında Hollanda konsolosu Hochepied ve ailesi gelmektedir. Hochepied'in evi 1960'lara kadar ayakta olmasına rağmen yüzey araştırması sırasında söz konusu evin bulunduğu alan incelenmiş ve günümüzde yalnızca evin temellerinin ve bahçe kapısının kaldığı görülmüştür (Şekil 12-13). Arazinin sahibi ise Hollanda Büyükelçiliği' dir. Kentteki Levanten kültürüne ilişkin olarak tarihsel bir geçmişe sahip olan bu yapının korunamamış olması Seydiköy'ün geçmişinin hatırlanmasındaki kayıplardan biridir. 
Hochepied'in eski eser düşkünlüğüne ilişkin farklı noktadan bir bilgiyi ise Francis Arundell vermektedir. Papaz Arundell, Konsolos Hochepied'in Seydiköy'deki evine gittiğinde bahçesinde bir sütunun kabartmalı alt kısmını gördügünü aktarmaktadır. Arundell'in Seydiköy'de karşılaştığı eski eser yalnızca bununla sınırlı değildi. Bunun dışında kilise bahçesinde üzerinde okunamaz bir yazı bulunan bir lahdin çeşme teknesi olarak kullanıldığını görmüş, ayrıca yine kilisenin bahçesinde birkaç Yunanca yazıtı, çeşitli sütun ve sütun başlığ parçalarını gözlemleme imkânını bulmuştur (Arundell 1828, 12).

Arundell'e göre bahçede karşılaşmış olduğu eski eserler Seydiköy'de ya da yakınlarında bir antik kentin bulunduğunun kanıtı niteliği taşımaktadır. Buna karşın Seydiköy ve çevresinde gerçekleştirilen yüzey araştırmaları kentin şehirleşmesi sürecinde büyük bir gelişim ve dönüşüme uğradığını ortaya koymaktadır. Konuya ilişkin olarak Seydiköy'de bir zamanlar antik kalıntılar bulunduğunu içeren bilgiler farklı seyyahlar tarafından da dile getirilmektedir. Anadolu'da seyahatler yapan Walpole, Yunanca yazıtlı bir mermerin İzmir'in güneyindeki Seydiköy'de (Sedgikeui) bulunduğunu, 1732 yılında İngiltere'ye götürülüp sonrasında da Cambridge Üniversitesi'ne sunulduğunu belirtmektedir (Walpole 1820, 1). Mermer yazıtın içeriğine bakıldığında Attalos'un koruması altındaki Hellespontos ve Ionia kıyılarındaki aktör ve müzisyen topluluklarının birliğine ilişkindir. Bir flütçü olan Zotichos'un oğlu Pergamonlu Krato'nun onurlandırıldığı yazıtta, müzisyenin mesleğine ilişkin bilgiler verilmektedir (Walpole, 1820: 7). Söz konusu bilgiler 12 Ion kentinden biri olan Smyrna'nın güney kesiminde de antik çağda etkinliklerin sürdürülmekte olduğunu göstermektedir.

Seydiköy'ün kuzeyine doğru, 1.5 mil uzaklıkta bulunan küçük bir akarsu ile değirmenin varlığından söz eden Arundell, değirmenin yanında antik duvar kalıntılarının izleriyle karşılaşmıştır. Muhtemelen değirmen, bir antik kalıntı üzerine inşa edilmiş ya da belki de değirmenin inşasında eski taşlar devşirme malzeme olarak kullanılmıştır. Hemen yukarısındaki alan ise Türk Mezarlığı olarak kullanılmakla birlikte burasının da antik kalıntılar barındırdığına vurgu yapmaktadır (Arundell, 1828: 13);

"Burada iki adet yazıt buldum. Bunlardan biri Hyrcania kenti tarafindan Imparator Gallus ve Volusianus'a ithaf edilmiş olan sütun parçasıydı."

Söz konusu arkeolojik kanıtlar yoluyla Arundell, Hyrcania kentinin Seydiköy yakınlarında olabileceğini belirtmekle birlikte Albay Leake, bu yoruma ilişkin notunda söz konusu kentin Thyatira'dan fazla uzakta bulunamayacağını, Seydiköy'deki yazıt içeren mermerlerin ise Smyrna' dan getirilmiş olabileceğini vurgulamaktadır (Arundell, 1828: 13). Benzer bir biçimde Ramsay da Hyrcania ovasını, Sardis (Salihli) ise Magnesia (Manisa) arasında, Hermos (Gediz) nehri yakınlarına lokalize etmektedir (Ramsay, 1960: 134).

Seyyahların aktarmış olduğu bilgilerin yanı sıra ele geçmiş olan farklı buluntular Seydiköy'ün arkeolojik zenginliği ile ilgili olarak fikir vermektedir. Bunlardan biri İzmir-Ephesos yolunun tamiri için yapılan Vespasianus dönemine tarihlenen iki adet kilometre taşıdır. Söz konusu taşlar Seydiköy yakınlarında bulunmuştur (Magie, 1950: 795). Seydiköy'de bulunan mil taşlarının yanı sıra Metropolis'ten Belevi ve Ahmetli köyü yakınlarındaki mil taşlarının varlığı Ephesos ile Smyrna arasındaki antik yolun güzergâhını ve uzunluğunu göstermekle birlikte (Tuna, 1988: 304) Seydiköy'ün de antik çağlarda bu iki önemli kent arasındaki ticaret yolu üzerinde yer aldığını göstermektedir. Bu nedenle ele geçen ve Avrupalı seyyahlarca sözü edilen eski eserler yerleşimin bu stratejik konumu ile ilişkili olmalıdır. 
Yörede Arkaik dönemdeki etkinliklerle ilgili olarak kanıt sağlayan bir örnek ise R. Meriç tarafından gerçekleştirilen yüzey araştırmaları sırasında Görece yakınlarında bulunan kireç taşından bir yazıttır. Geç MÖ 6. yüzyıla tarihlenen Arkaik bina yazıtı ya da sanatçıların imzası olarak tanımlanabilen yazıt boustrophedon stilinde yazılmıştır (Meriç, 1988: 248; Meriç \& Nollé, 1988: 225-232).

$\theta \mathrm{os}: \kappa \alpha \grave{\mathrm{i}} \mathrm{K} \alpha-$

$\lambda \omega \mu \alpha v \delta Q-$

o५: $\kappa \alpha i \mathrm{~T} \varepsilon \lambda \varepsilon-$

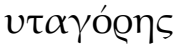

$\varepsilon \dot{\pi} \pi$ oí $\sigma<\alpha>v$.

(Bunu?) -tbos ve Kalomandros ve Teleutagoras yaptı.

\section{Sonuç}

Seydiköy'ü ziyaret eden Avrupalı seyyahlar kendi dönemlerine ilişkin güncel bilgiler paylaşırken bölgenin antik kalıntıları üzerine de değerli bilgiler sunmuşlardır. Bunların içerisinde Seydiköy ve çevresinin Avrupa müzelerine taşınabilecek içeriğe sahip antik kalıntıları barındırmış olması arkeolojik zenginliğini ortaya koymaktadır. Sonrasında gerçekleştirilen keşifler de benzer biçimde yörenin antik çağda Smyrna'ya uzanan güzergâh üzerinde stratejik bir noktada olduğunu göstermekle birlikte kentin büyüme ve gelişme sürecinde birçok antik kalıntının kaybolmuş olduğu görülmektedir. Seyyahlar tarafından sıklıkla dile getirilen tümülüslere ilişkin, günümüzde ancak bir tanesinin muhafaza edilebilmiş olması bunun bir göstergesidir. Önceki araştırmalarda ve tarafımızdan gerçekleştirilen yüzey araştırması sırasında arkeolojik bulgulara ulaşılması da erken dönem seyyahlarının Seydiköy'ün antik kalıntılarına ilişkin vurgularını destekler niteliktedir. Özellikle süregelen arkeolojik bulgular Seydiköy'ün kuzey-güney doğrultusunda Ephesos'tan Smyrna'ya uzanan yol üzerinde antik çağlardaki stratejik konumunu göstermektedir.

Avrupalı seyyahların verdiği bilgiler ile kesişen bulgularla karşılaşılmasına karşın bazı örnekler seyyahlar tarafından kimi kalıntıların, yapıların gözden kaçırılmış olduğunu da göstermektedir. Örneğin Akçakaya'da kalenin içinde zirveye yakın bir noktada kutsal alan izlenimi veren basamaklı bir oluşum görülürken, Weber' in burada incelemeler yapmasına ve Akçakaya'ya ilişkin bir makale yazmasına karşın bundan söz etmemesi dikkat çekicidir. Bununla birlikte yüzey araştırması sırasında bulunan bir mortarium (buğday öğütme çanağı), cam ve seramik cürufları Seydiköy ve çevresinde Antik Çağ'da endüstriyel üretime yönelik bir yerleşme olduğunun kanıtlarını sunmaktadır.

Son olarak Seydiköy tümülüsleri örneğinde görüldüğü gibi bölgenin arkeolojik mirasının yoğun bir tehdit altında olduğunu söylemek mümkündür. Akçakaya Akropolü'ndeki ve yamaçlar boyunca açılmış olan günümüzdeki çukurlar tepenin kaçak kazılar yoluyla zarar gördüğünü açık biçimde göstermektedir. 


\section{Teşekkür}

Çalışmamıza konu olan iki tümülüs ile ilgili olarak arşivinde yer alan fotoğraflarını bizimle paylaşan Arkeolog Ercan Çokbankir'e teşekkürlerimizi bildiririz.

\section{Kaynakça}

Arundell, FR. V.J. (1828). Visit to the Seven Churches of Asia, with an Excursion Into Pisidia; Containing Remarks on the Geography and Antiquities of Those Countries. London: John Rodwell.

Bond, A. (1828). Memoir of the Rev. Pliny Fisk, A.M. Late Missionary to Palestine, From the American Board of Mission. Edinburgh: Crocker \& Brewster.

Cadoux, C.J. (2003). İlkçă̆'da İzmir: Kentin, En Eski Çă̆lardan İ.S. 324'e Kadar Tarihi. Çev. B. Umar. İstanbul: İletişim Yayınları.

Chandler, R. (1817).Travels in Asia Minor. London: Joseph Booker.

Cricca, A. (1868). Cholera in the Orient, and Its Successful Treatment, and Prophylaxis, in the Epidemic of 1865. Chicago: C.S. Halsey.

Davis, E.J. (1874). Anatolica: Or, The Journal of a Visit to Some of the Ancient Ruined Cities of Caria, Phrygia, Lycia, and Pisidia. London: Grant \& Co.

Dearborn, H.A.S. (1819). A Memoir on the Commerce and Navigation of the Black Sea and the Trade and Maritime Geography of Turkey and Egypt, Vol. II. Boston: Wells \& Lilly.

Doğer, E. (2006). İzmir'in Smyrnası Paleolitik Çă̆'dan Türk Fethine Kadar. İstanbul: İletişim Yayınları.

Emerson J. (1829). Letters from the Ægean. New York: J. \& J. Harper, Cliff St.

Fellows, C. (1838). A Journal written during an Excursion in Asia Minor. London: John Murray.

Frankel, R. (2003). The Olynthus Mill, Its Origin, and Diffusion: Typology and Distribution. American Journal of Archaeology, 107(1), 1-21.

Fuller, J. (1830). Narrative of a Tour Through Some Parts of the Turkish Empire. London: John Murray.

Hasselquist, F. (1766). Voyages and Travels in the Levant in the Years 1749, 50, 51, 52: Containing Observations in Natural History, Physick, Agriculture, and Commerce, Particularly on the Holy Land and the Natural History of the Scriptures. London: L. Davis \& C. Reymers.

Jardine W. (1858). Memoirs of Hugh Edwin Strickland. Cambridge: John Van Voorst.

MacGill, T. (1839). Travels in Turkey, Italy and Russia During the Years 1803, 1804, 1805, 1806; with an Account of some of the Greek Islands Vol. I. London: John Murray.

Magie, D. (1950). Roman Rule in Asia Minor, Vol. 2 (Notes): To the End of the Third Century After Christ. Princeton: Princeton University Press.

Meriç, R. (1988). 1986 Yılı İzmir ve Manisa İlleri Yüzey Araştırmaları. V. Araştırma Sonuçları Toplantısl, I, 6-10 Nisan 1986 Ankara, 247-256. 
Meric, R. \& Nollé, J. (1988). Eine archaische Inschrift aus dem Gebiet von Smyrna. Chiron, 18, 225-232.

Michoud, J.F. \& Poujoulat, J. J.F. (2007). İzmir'den İstanbul'a Batı Anadolu 1830. Çev. N. Demirtaş. İstanbul: İstiklal Kitabevi Yayınları.

Ramsay, W.M. (1960). Anadolu'nun Tarihi Coğrafyası. İstanbul: Milli Eğitim Bakanlığı.

Tuna, N. (1988). İonia ve Datça Yarımadası Arkeolojik Yüzey Araştırmaları 1985 - 1986. V. Araştırma Sonuçları Toplantısı, I. 6-10 Nisan 1986 Ankara, 303-358.

Walpole, R. (1820). Travels in Various Countries of the East; Being a Continuation of Memoirs relating to European and Asiatic Turkey. London: Longman, Hurst, Rees, Orme \& Brown.

Weber, G. (1885). Akdsché - Kaja. Eine unbekannte Felsburg bei Smyrna, Mittheilungen des Deutschen Archaologischen Institutes in Athen, 211-216.

Wheler, G. (1682). Journey Into Greece. 6 Books with Variety of Sculptures. London: W. Cademan, R. Kettlewell, A. Churchill.

\section{Açıklamalar}

1. Söz konusu çalışma İzmir ili, Merkez Giiney ilçelerinde (Buca, Karabağlar, Gaziemir, Balçova, Narlıdere ve Güzelbahçe ilçeleri) yürütülen 2018 yılı mimari-arkeolojik yüzey araştırmasının Seydiköy (Gaziemir) ile ilgili bulgularını içermektedir.

2. Yine de 1865 yılındaki incelemelerde bazı ailelerin koleradan etkilenmiş olduğu bilgisi verilmektedir (Cricca 1868, 24). 